\title{
PERAN ANTROPOLOGI BUDAYA DALAM RUANG LINGKUP PEMBELAJARAN IPS
}

\author{
Muhammad Maulana \\ Email:2010128210006@mhs.ulm.ac.id \\ Program Studi Pendidikan IPS Fakultas Keguruan dan Ilmu Pendidikan \\ Universitas Lambung Mangkurat \\ Banjarmasin
}

\begin{abstract}
Abstrak
Ilmu pengetahuan sosial atau sering kali yang disebut dengan IPS, yang menyatakan ilmu yang mengkaji tentang suatu bidang keilmuan dalam disiplin dibidang akademis yang menunjukkan bahwa sebuah IPS ini harus di pelajari dengan fokus kepada gejala sosial dan permasalahan sosial dimasyarakat maupun menyangkut budaya. dalam kaidah nya IPS, ilmu yang memadukan antara dari konsep ilmu ilmu sosial seperti antropologi, geografi, sejarah, ekonomi, sosiologi. politik, hukum. Antropologi ilmu yang memiliki makna artian dalam konteksnya sendiri yang menyajikan sebuah tentang manusia sebagai makhluk yang memiliki akal dan pikiran yang sempurna, ilmu antropologi ini yang dalam isi pokok pembahasaanya berfokus kepada manusia dari sisi pandang dan cara pemikirannya manusia agar terus berkembang yang bahwasanya antropologi memiliki cabang pokok utama, untuk menjadikan tiga bidang ilmu tersebut, yaitu antropologi budaya, arkeologi, serta antropologi fisik.
\end{abstract}

\section{PENDAHULUAN}

Ilmu pengetahuan sosial ialah ilmu yang mengkaji tentang suata bidang keilmuan dalam disiplin dibidang akademis yang menunjukkan bahwa sebuah IPS ini harus di pelajari dengan fokus kepada gejala sosial dan permasalahan sosial di masyarakat maupun menyangkut budaya (Syaharuddin, S., \& Mutiani, M. (2020:14). dalam kaidah nya IPS, ilmu yang memadukan antara dari konsep ilmu ilmu sosial seperti antropologi, geografi, sejarah, ekonomi, sosiologi. dalam pembelajaran IPS yang telah dilaksanakan dengan baik pada pendidikan dasar yang menunjang dalam pendidikan tinggi yang menekan akan pada aspek yang mengandung teoritis dalam keilmuan IPS ini menuntut kepada aspek tentang lingkungan masyarakat (Syaharuddin, S., \& Mutiani, M. (2020: 13), budaya yang dapat diketahui bahwasanya IPS memiliki tujuan dalam pembelajaran untuk menumbuhkan sebuah pengetahuan dan keterampilan pada peserta didik untuk lebih bermanfaat dalam lingkungan sekitarnya untuk lebih bisa aktif dalam berpartisipasi untuk menjalankan pendidikan dan termasuk akan dalam peran sebuah komponen penting untuk 
mengsignifikan yang mengarahkan dalam memperhatikan akan tentang sosial yang berada dalam kehidupan untuk membangun nilai dalam pembelajaran IPS.

Antropologi ilmu yang memiliki makna artian dalam konteksnya sendiri yang menyajikan sebuah tentang manusia sebagai makhluk yang memiliki akal dan pikiran yang sempurna, ilmu antropologi ini yang dalam isi pokok pembahasaanya berfokus kepada manusia dari sisi pandang dan cara pemikirannya manusia tersebut serta tingkah laku dan cara manusia menghadapi tingkat cara bepikirnya yang sederhana hingga modern, antropologi memiliki cangkupan yaitu antropologi budaya dan sosial. Jadi ilmu antropologi ini memiliki perubahan pada tahapanya sendiri seperti membawa kejalan negatif maupun positif dalam pencapaian manusia terhadap sosial dan budaya yang ada dikalangan masyarakat ini yang mengandung nilai tata cara hidup manusia seperti yang hal nya pergaulan dalam masyakarat dan memiliki tujuan dalam hal peran antropologi budaya dalam pembelajaran IPS.

\section{METODE}

Metode yang dipakai dalam penyusunan penelitian artikel ini, adalah metode desktriptif, pada metode ini menggambarkan apa adanya tentang tujuan Ruang lingkup antropologi, yang dimana untuk ditunjukkan dari hasil penilitian ini seperti mengumpulkan data-data, sumber serta jurnal dan refrensi lainnnya yang memberikan penelitian artikel dapat disusun dan di deskriptifkan dengan konsep pada pembelajran IPS dalam rumusan masalah dari berbagai karya ilmiah, sehingga mendapatkan hasil gambaran tentang penelitian pada artikel ini yang dibuat dalam penulisan.

\section{KONSEP RUANG LINGKUP ANTROPOLOGI}

Sebagai ilmu yang dikatakan sempurna Antropologi yang memiliki artian sebagai ilmu yang mempelajari tentang manusia yang memiliki pikiran yang luas serta makhluk yang paling sempurna di antara berbagai makhluk yang ada dibumi ini, dan sebagaimananya mengungkapkan sebuah kehidupan yang mana memiliki kemampuan yang kreatif dalam fisik dan ciri-ciri manusia yang menopang dalam kelangsungan kehidupan yang menjadikan antropologi sebagai ilmu yang dalam pengertiannya itu measumsikan tentang manusia. dalam mempelajari Antropologi ini ilmu yang sangat disiplin yang telah memperoleh atau menguasai tentang kehidupan manusia yang memiliki jiwa sosial. sebagaimana kita dapat rasakan antropologi itu ilmu yang 
paparannya terus berubah, yang dimana dapat dikatakan mengapa terus berubah yang dalam artian sangat berarti dalam kehidupan manusia agar terus berkembang yang bahwasanya antropologi memiliki cabang pokok utama, untuk menjadikan tiga bidang ilmu tersebut, yaitu antropologi budaya, arkeologi, serta antropologi fisik.

Konsep ruang lingkupnya antropologi yang dimana dalam kaidahnya masingmasing memiliki bidang konsep nya dalam ilmu antropologi ini untuk menjadikan bidang ilmu yang mandiri dalam akan hubungan yang memiliki satu sama lain, pada cakupannya merupakan salah satu dari karakteristik yang paling diutamakan atau yang paling banyak banyak pendapat tentang ruang lingkupnya antropologi dari bagian secara makronya ilmu yang dapat diambil yaitu antropologi budaya dan fisik, dan dimana dalam konsep ruang lingkup ini antropologi memiliki juga tentang hubungan sebagaimana bidangnya dalam ilmu pengetahuan dan teknologi yang mengkaji akan hampir menyeluruh hakikat dan pribadi masyarakat secara lain dalam diri individu, yang dimana mengendalikan kepedulian akan terciptanya pembelajaran dalam ilmu pengetahuan yang berhubungan langsung denga antropologi ini terdapat dalam banyak hal nya cakupan tempat dalam ilmu antropologi didalam jangkauan serta spekualasi pada ilmu ilmu lainnya. Penjelasan pada konsep ruang lingkup ini yang menyertai terhadap objek dan subjek dalam jalannya perkembangan ilmu antropologi ini karena memiliki perspektif akan ilmiah yang tercantum dalam unsur- unsur pokok yaitu seperti Empiris memiliki makna pengetahuan yag diperoleh berdasarkan dalam pengamatan dan percobaan manusia untuk lingkungan pada masyarakat, budaya, suku, bangsa. dan atas pada dasarnya dalam materi konsep ruang lingkup antropologi ini hanyar untuk memperluas dan memperkembangkan pada ilmu antropologi tersebut.

\section{PERAN ANTROPOLOGI BUDAYA UNTUK PEMBELAJARAN IPS}

Antropologi budaya memiliki yang dalam artian yang fokus kepada pedulinya terhadap kebudayaan yang mencakup tentang manusia, pada dasarnya tambahan dari antropologi untuk menyesuaikan akan gunanya dalam ilmu pengetahuan yang dimana saat tumbuh dengan pesatnya dengan perubahan peradaban manusia saat ini yang mencakup permasalahan yang menjadi titik fokus pada antropologi budaya ini yang menerangkan bahwa timbal balik antara manusia dan kebudayaan pada bangsa ini yang memiliki suatu ruang dan pada masa tertentunya, dalam kaidahnya hal kebudayaan sangat dipandang sebagai wujud dari hasil cipta manusia yang disatu sisi kebudayaan itu sebagai 
sarana yang bisa untuk hidup dalam unsur-unsurnya antropologi budaya (Simanjuntak, G. P. (2021). yang memiliki setiap kebudayaan sebagai universal dalam unsur ini kebudayaan memiliki bahasa, organisasi, ilmu pengetahuan, kesenian, sarana teknologi, religi, mata pencaharian dan kesenian. yang dimana pada kenyataannya antropologi budaya ada dikarenakan dibuat oleh manusia itu untuk memenuhi kekurangan dalam hidup nya yang dimana sebagai suatu sarana yang menjadi arah tercipta suatu antropologi budaya ini untuk menjadi pedoman hidup manusia dalam menghadapi kehidupan. Antropologi budaya menekan tentang yaitu dengan pertimbangan politik, menyangkut hubungan kebudayaandengan kekuasaan, menyangukut bahasa, menyangkut kepribadian tetang sifat pada diri manusia .pada kajian dalam konsep kebudayaan yang bersifat plural, relative, holistic tersebut.

Peran antropologi budaya yang berhubungan dengan pembelajaran IPS yang dimana dapat diketahui bahwasanya keduanya untuk menyatukan bahan ajaran setiap kajian pada ilmu sosial ini, untuk mengembangkan banyak prinsip hal dalam mengembangkan suatu pembelajaran dalam pengalaman atas hasil belajar pada peserta didik untuk mampu mempersiapkan akan mampu bersaing secara aktif dalam kehidupan masyarakat yang mengandung unsur penerapan kebudayaan, yang dimana setiap pada aspek antropologi budaya ini akan menjadikan objek studi dalam intreraksi sosial nya untuk menerapkan banyak hal disisi lingkungan yang memiliki kebudayaan untuk dapat dipadukan menjadi hal nya mempunyai keterkaitan yang khusus dalam proses pembelajaran IPS Ini untuk menciptakan bentuk hasil dari kebudayaan dengan adanya perkembangan dalam keadaanya yang sederhana untuk memajukan pada sumber pembelajaran dan materi yang diajarkan dalam konsep pembelajaran IPS ini untuk mengatahui bagaimana daya adaptasi manusia dalam konteks suasana antropologi budaya yang mendapat dalam macam keanekaragaman bersangkutan akan dalam disajikannya pada pembelajaran IPS dapat paduan dari sejumlah paham akan budaya dalam dislpin ilmu ini untuk mengetahui dan mempelajari manusia sebagai masyarakat untuk menjaga kebudayaan dan melaksanakan prinsip akan pentingnya antropologi budaya ini dalam peranya mewujudkan untuk mengetahui kepada manusia, atau masyarakat akan pentingnya dalam sangkutanya di pembelajaran IPS.

\section{SIMPULAN}


Ilmu pengetahuan sosial ialah ilmu yang mengkaji tentang suata bidang keilmuan dalam disiplin dibidang akademis yang menunjukkan bahwa sebuah IPS ini harus di pelajari dengan fokus kepada gejala sosial dan permasalahan sosial di masyarakat maupun menyangkut budaya. dalam kaidah nya IPS, ilmu yang memadukan antara dari konsep ilmu ilmu sosial seperti antropologi, geografi, sejarah, ekonomi, sosiologi. dalam pembelajaran IPS yang telah dilaksanakan dengan baik pada pendidikan dasar yang menunjang dalam pendidikan tinggi yang menekan akan pada aspek yang mengandung teoritis dalam keilmuan IPS ini menuntut kepada aspek tentang lingkungan masyarakat.

Konsep ruang lingkupnya antropologi yang dimana dalam kaidahnya masingmasing memiliki bidang konsep nya dalam ilmu antropologi ini untuk menjadikan bidang ilmu yang mandiri dalam akan hubungan yang memiliki satu sama lain, pada cakupannya merupakan salah satu dari karakteristik yang paling diutamakan atau yang paling banyak banyak pendapat tentang ruang lingkupnya antropologi dari bagian secara makronya ilmu yang dapat diambil Antropologi budaya memiliki yang dalam artian yang fokus kepada pedulinya terhadap kebudayaan yang mencakup tentang manusia, pada dasarnya tambahan dari antropologi untuk menyesuaikan akan gunanya dalam ilmu pengetahuan yang dimana saat tumbuh dengan pesatnya menjadikan suatu perubahan peradaban manusia saat ini yang mengalami masalah dalam kebudayaan nya.

\section{REFERENSI}

Abbas, E. W. (2021, May). Banua Anyar Culinary Tourism Area: Study Of Economic Activities As A Learning Resource on Social Studies. In IOP Conference Series: Earth and Environmental Science (Vol. 747, No. 1, p. 012019). IOP Publishing

Indriyani, I. E., Syaharuddin, S., \& Jumriani, J. (2021). Social Interaction Contents on Social Studies Learning to Improve Social Skills. The Innovation of Social Studies Journal, 2(2), 93-102.

Jumriani, J. (2020). Interaksi Sosial Pedagang Kain Sasirangan di Kampung Sasirangan Banjarmasin untuk Mempertahankan Kelangsungan Industri.

Mutiani, M., Abbas, E. W., Syaharuddin, S., \& Susanto, H. Membangun Komunitas Belajar Melalui Lesson Study Model Transcript Based Learning Analysis (TBLA) dalam Pembelajaran Sejarah. Historia: Jurnal Pendidik dan Peneliti Sejarah, 3(2), 113-122.

Mutiani, M., Noortyani, R., Tetep, T., Jumriani, J., \& Widyanti, T. (2020). Strengthening Islamic Environmental Awareness through Exploring Poetry as a Learning 
Resource in Social Studies. Islam Realitas: Journal of Islamic and Social Studies, 6(2), 153-166.

Muchtar, K., Koswara, I., \& Setiaman, A. (2016). Komunikasi antar budaya dalam perspektif antropologi. Jurnal Manajemen Komunikasi, 1(1).

Rahayu, R., Abbas, E. W., \& Jumriani, J. (2021). Social Studies Lesson Planning for Children with Intellectual Disabilities in the Pembina State Special School of South Kalimantan Province. The Kalimantan Social Studies Journal, 2(2), 160-169.

Simanjuntak, G. P. (2021). Antropologi Budaya

Syaharuddin, S., \& Mutiani, M. (2020). Strategi Pembelajaran IPS: Konsep dan Aplikasi.

Syaharuddin, S., Samihati, M., \& Jumriani, J. (2020). AKTUALISASI SIKAP PEDULI LINGKUNGAN MELALUI AKTIVITAS PENGELOLAAN SAMPAH. Jurnal Socius, 9(2), 193-203. 